several months, when the whole adventure is brought to a sudden and dramatic close. On June Io Captain Tibbetts telegraphs, collect, to the effect that "about I 5 or 20 men boarded the Boston at half past 9 o'clock last night at Papa Loutre [?] while I was towing in the Bark Jenny Lind. I was on board the Bark at the time, they cut the ropes \& left so quick I had not time to get on board the Boston."

The epilogue appears in a letter written in 1867 , from Havana, by the captain of another boat, apparently an acquaintance of Wilder's.

"While taking a sail in my boat the other day," it runs, "I thought $I$ recognized an old acquaintance in a rusty looking tug lying away up in the Guanabacoa corner of the bay, and on boarding ascertained that she was the historical 'Boston.'

"She is claimed by parties in Mobile, has a ship-keeper on board. her hull is in good order (but bare of paint) one mast standing, engine not been taken care of, looks rusty, so can not speak for that without proper examination. If I can assist you in reclaiming her, please write me."

Whether or not the "Boston" was ever reclaimed, we do not know, for with this forlorn picture the letters leave her.

\title{
New Committee for the Preservation of Historical Data
}

The American Council of Learned Societies has recently formed, in conjunction with The Social Science Research Council, a committee on the enlargement, improvement and preservation of data. Professor Norman S. B. Gras, of Harvard University, has been appointed a member. The work of the committee will be to discover the needs of scholars who are engaged in research in the humanities and the social sciences. Presumably action will be taken later to assist investigators in these subjects. It is obvious that the committee will be doing about the same kind of work as The Business Historical Society, but in a more comprehensive field. 